\title{
A Historical Assessment of the Rationales and Functions of Reserve Requirements
}

\author{
Marvin Goodfriend and Monica Hargraves*
}

I.

INTRODUCTION

Laws requiring banks to hold a volume of reserves equal to a prescribed fraction of their deposits originated in this country more than a century ago. Since then both the financial system and the rationales supporting reserve requirements have changed considerably. Nevertheless, the practice of requiring reserves has continued without interruption. This article examines the history and function of reserve requirements at the national level and assesses the validity of various prominent reserve requirement rationales.

Section II reviews the history of reserve requirements, focusing on the succession of rationales that have supported major reserve requirement legislation. The prominent rationales have been, in turn, that reserve requirements have been necessary for liquidity provision, Federal Reserve credit policy, and monetary control. However, the discussion in Section II explains that reserve requirements have never served these functions well, and often have not served them at all. On the other hand, reserve requirements have consistently functioned to help finance the United States Treasury. Section III describes the financing function of reserve requirements and documents its importance in reserve requirement legislation throughout the history of the Federal Reserve System up to and including the Monetary Control Act of 1980. The analysis is summarized in the conclusion.

II.

\section{CRITIQUE OF PROMINENT RESERVE REQUIREMENT RATIONALES}

The prominent rationales for reserve requirements at the national level can be roughly separated according to the periods in which they were popular. The argument that reserve requirements are necessary for providing bank liquidity was offered in support of reserve requirements from their initial imposition at the national level during the Civil War through the creation of the Federal Reserve System. The argument that reserve requirements contributed importantly to Federal Reserve credit policy became prominent in the early years of the Federal Reserve System. The credit policy rationale has since evolved into the argument that reserve requirements are useful for monetary control. This section discusses each rationale in turn, explaining both theoretically and practically where appropriate why reserve requirements have rarely functioned as indicated in the standard rationales.

\section{Liquidity Provision}

Reserve requirements on bank deposits were first established at the national level in 1863 with the passage of what is known as the National Bank Act. The main provisions of the National Bank Act helped to create a uniform national currency and provided banks with an alternative to a state charter by establishing a national charter under which they could organize. Banks with national charters were required to keep a 25 percent reserve against both note and deposit liabilities. For national banks in "redemption cities" designated in the Act, the reserve was to be held entirely in lawful money (specie and greenbacks) in the bank's vault. Banks outside the redemption cities were permitted to hold threefifths of their required reserves with national banks in redemption cities. Since interbank deposits paid interest and provided other benefits, this rule greatly reduced the cost of required reserve maintenance for non-redemption relative to redemption city banks.

\footnotetext{
* Marvin Goodfriend is a Research Officer at the Federal Reserve Bank of Richmond, currently visiting the Econometric and Computer Applications Section, Board of Governors of the Federal Reserve System. Monica Hargraves is an Assistant Economist at the Federal Reserve Bank of Richmond.
} 
When the National Bank Act was rewritten in 1864, reserve requirements of non-redemption city banks were reduced to 15 percent and, in addition, banks in redemption cities other than New York were permitted to hold one-half of their required reserves with national banks in New York City. In effect, the percent reserve required to be held in lawful money in a bank's vault was "graduated" from 25 percent for New York City banks, to 12.5 percent for redemption city banks outside of New York City, to 6 percent for non-redemption city banks. The reduction in the reserve requirement burden for banks outside of New York City helped to increase the attractiveness of a national relative to a state charter. This was important, since membership in the National Banking System was voluntary, in keeping with the so-called "dual banking system tradition," i.e., the coexistence of state and Federal regulatory authorities, established with the National Bank Act.

Reserve requirements in the National Bank Act were apparently rationalized as being necessary to ensure bank liquidity, that is, the ability of banks to convert deposits into currency. ${ }^{2}$ The geographically graduated reserve requirement structure seemed consistent with the liquidity rationale, since roughly speaking, the more central a bank's position in the financial system, the more lawful money required reserves it had to hold.

Reserve requirements could have completely guaranteed convertibility if the required reserve ratio had been 100 percent in lawful money in the bank's vault. A reduction in deposits would then have reduced required reserves by an equal amount, releasing enough funds to meet the withdrawal. However, 100 percent reserve requirements would also have imposed a considerable burden on banks, and would have been difficult to enforce since national banks had the alternative of a state charter, which generally carried with it relatively low or zero reserve requirements on deposits. On the other hand, with the fractional reserve requirements specified in the National Bank Act a withdrawal only released a portion of the funds demanded by the depositor.

${ }^{1}$ Original Acts Pertaining to National Banks . . [39], pp. 19-20, 43-44. See Board of Governors [12], pp. 955-56.

${ }^{2}$ It should be noted that an important motive underlying the National Bank Act was the need to finance the Civil War. One device designed in part to help finance the War was the requirement that National Bank notes be backed by government bonds. By tying note issue to bond holdings the government attempted to enlarge the demand for its debt. See Davis [22]; Hammond [33 34]; and Million [37] for discussions of the origins of the National Bank Act. Newcomb [38] contains a critical appraisal of the National Bank Act as a warfinancing measure.
Since required reserves held against other deposits could not be used without penalty, an individual bank's ability to convert deposits into currency still depended on its excess reserves or secondary reserves in the form of assets which could be easily sold. Furthermore, although reserve requirements contributed somewhat to individual bank liquidity, the banking crises of 1873, 1893, and 1907 demonstrated that fractional reserve requirements could not guarantee sufficient liquidity for the banking system as a whole. ${ }^{3}$

The main contemporary criticism of the reserve requirement provisions in the National Bank Act was that they continued to allow a "pyramiding" of reserves in financial center banks. The practice of counting correspondent balances as legal reserves, combined with the fact that banks could earn interest on their deposits with banks in major cities, meant that reserves tended to concentrate in the major cities, especially in New York City. Reduction of these interbank balances in peak agricultural periods in particular tended to put contractionary seasonal pressure on banks in the major cities, and, in turn, on banks throughout the country.

The Federal Reserve Act of 1913 was in large part designed to alleviate the two main problems of the National Bank Act era, namely, recurrent liquidity crises and seasonal contractions due to reserve pyramiding. Specifically, as stated in its preamble, the purposes of the Federal Reserve Act were "to provide for the establishment of Federal reserve banks, to furnish an elastic currency, to afford means of rediscounting commercial paper, to establish a more effective supervision of banking in the United States, and for other purposes. “4 The rediscounting mechanism, which allowed Federal Reserve member banks to borrow from Federal Reserve Banks using eligible paper as collateral, helped to guarantee liquidity by providing a readily accessible source of reserves for the banking system. By requiring that member banks hold reserves directly in one of the twelve Federal Reserve Banks, the Federal Reserve Act eliminated pyramiding and made the banking system less vulnerable to seasonal fluctuations in reserve needs.

Apparently, reserve requirements continued to be imposed under the Federal Reserve Act on the basis

\footnotetext{
${ }^{3}$ See Sprague [45] for a detailed discussion of bank crises in the National Banking era.

" "Federal Reserve Act of 1913" [24], p. 25. See Friedman and Schwartz [28]. pp. 168-72, 189-96 for a discussion of the need to furnish an elastic currency. For discussion of the drafting of the Federal Reserve Act, the proposals that preceded it, and a comparison, see Willis [67]; U. S. National Monetary Commission [64]; and Warburg [65] respectively.
} 
of the liquidity rationale. The Federal Reserve Act retained, for reserve requirement purposes, the classification of banks under the National Bank Act in what were known as central reserve city, reserve city, and country. bank categories. In addition, the Federal Reserve Act went further and distinguished between demand and time deposits for reserve requirement purposes. Reserve requirements on demand deposits were reduced to 18,15 , and 12 percent on central reserve city, reserve city, and country banks respectively. But the net effect of these reductions on reserve city and country banks must also take account of the fact that these classes of banks could no longer partially satisfy reserve requirements by holding interest-earning correspondent balances. On net, noninterest-earning reserve requirements against demand deposits were lowered for central reserve city banks, but raised for both reserve city and country banks. However, all classes of banks benefitted from the relatively low 5 percent reserve- requirement on time deposits. The substantial differential in favor of time deposits was apparently established to enable member banks to compete more effectively with state-chartered banks, who generally had a lower or zero reserve requirement on time deposits. ${ }^{5}$ This was beneficial since Federal Reserve membership was voluntary, in keeping with the tradition of choice established with the National Bank Act. ${ }^{6} \quad$ The dual banking system tradition constrained the Federal Reserve and was to become an important issue in later reserve requirement legislation.?

By the 1920s, Fed policy had grown from an almost purely defensive operation trying to ensure convertibility and avert crises to one of actively attempting to influence credit conditions. A new rationale for reserve requirements emerged along with this shift in Fed policy and the liquidity rationale was officially rejected in the report of the 1931 Federal Reserve system Committee on Bank Reserves:

The committee takes the position that it is no longer the primary function of legal reserve requirements to assure or preserve the liquidity of the individual member bank. The maintenance of liquidity is necessarily the responsibility of bank management and is achieved by the individual bank when an adequate proportion of its portfolio consists of assets that can be readily converted into cash. Since the establishment of the Federal Re-

${ }^{5}$ See U. S. Congress, House [48], p. 73.

${ }^{6}$ Although Federal Reserve membership was mandatory for national banks, banks could voluntarily choose a national or a state charter.

${ }^{7}$ For good discussions of the history of the dual banking system tradition and how that tradition constrained the Fed, see Federal Reserve Committee on Branch, Group, and Chain Banking [27], and Wingfield [68]. serve System, the liquidity of an individual bank is more adequately safeguarded by the presence of the Federal Reserve banks, which were organized for the purpose, among others, of increasing the liquidity of member banks by providing for the rediscount of their eligible paper, than by the possession of legal reserves.

\section{Fed Credit Policy}

As the following quote from the 1931 Fed Committee on Bank Reserves indicates, the role attributed to reserve requirements in Fed credit policy served as the new rationale for their continued imposition :

The most important function served by member bank reserve requirements is the control of credit. ... The overexpansion of credit may take a particular form, such as excessive loans on farm lands, on urban real estate, or on securities, or it may be more general applying to a wide range of bankable assets.... It is the function of reserve requirements to restrain such overexpansion by making it necessary for banks to provide for additional reserves before they expand their credit.9

As a practical matter, reserve requirements did not function well to control credit and played only a minor role in the execution of Fed credit policy in the 1920s. The Fed Committee on Bank Reserves itself admitted :

In 1928 and 1929, however, during the most extravagant phases of the stock-market boom, excessive credit demands were reflected in an increase in borrowings from nonbanking lenders, and an unprecedented increase in the activity of bank deposits without an increase in their total volume. Reserve requriements, consequently, failed completely during those crucial years to act as a brake on the unsound use of credit.

Throughout most of the 1920s, and most of the early years of the Federal Reserve System as well, the discount rate was the primary Fed policy instrument. During much of this period the discount rate was set below even the call money rate received on loans with essentially no risk of default, thereby making it profitable for the banking system to borrow continuously at the Reserve Banks. ${ }^{11}$ For example, member bank discount window borrowing was roughly 2 billion dollars or above throughout 1919 and 1920, even exceeding member bank reserve balances at the Fed. For the decade as a whole, discounts made up over half of Federal Reserve credit outstanding.

${ }^{8}$ Committee on Bank Reserves [20], pp. 260-61.

${ }^{9}$ Ibid., pp. 264-65.

${ }^{10}$ Ibid., p. 265.

${ }^{11}$ Historical statistics referred to throughout this discussion may be found in Board of Governors [8], Sections 9,10 , and 12 . 
The Fed influenced market interest rates and credit conditions throughout the period primarily by manipulating the discount rate. The discount rate was raised to restrain credit and lowered to encourage credit expansion. Use of the discount rate in this. manner meant that credit, money, and required reserves were largely accommodated in the short run at a given discount rate. To the extent that reserve demand was simply accommodated, reserve requirements could not exercise an effective constraint on credit expansion. Reserve requirements played a role only to the extent that Fed nonprice rationing at the discount window made interest rates rise relative to the discount rate as discount window borrowing increased. In this case, an increase in required reserve demand associated with an increase in the demand for credit would only be accommodated at an increased spread of the market interest rate over the discount rate. Since Fed nonprice rationing at the discount window was relatively weak at the time, required reserves at best played only a minor role in restricting credit expansion during these years.

In the 1930s interest rates declined to a fraction of the levels they had averaged in the 1920s and although the Federal Reserve discount rate also fell, it was not allowed to fall as far. In contrast to the period between 1919 and 1931 when the discount rate was mainly below market rates, from 1934 on it was mainly above them. As a result, discounts were negligible in the latter period, and the discount rate fell into disuse as an instrument of credit policy.

Due to low credit demand and extremely low interest rates in the 1930s, required reserves were not needed to control credit. In fact, the mid-1930s was characterized by enormous growth in excess reserves relative to historical levels. These abnormally large excess reserves were probably due to a combination of very low interest rates and increased demand for liquidity due to the banking crises of the early 1930s. At any rate, Fed officials gradually became concerned about the potential inflationary consequences of the large volume of excess reserves. Using it recently acquired power to change reserve require ments, the Federal Reserve Board doubled reserve requirements in a series of steps in 1936-37 saying that its action "was in the nature of a precautionary measure to prevent an uncontrollable expansion of credit in the future. ${ }^{\prime 12}$

\footnotetext{
${ }^{12}$ Board of Governors [6] 1937, p. 2.

The Federal Reserve Board first acquired the Dower to change reserve requirements in the Thomas Amendment to the Agricultural Adjustment Act of 1933. That legislation authorized the Board, subject to Presidential approval, to change reserve requirements upon declaration
}

Given the Fed's judgment of the advisability of attempting to immobilize excess reserves, its decision to raise reserve requirements rather than sell securities from its portfolio seems justifiable. At the time of the initial reserve requirement increase in August 1936 excess reserves were approximately 3 billion dollars, while the Fed's total portfolio of earning assets, by then essentially government securities, was roughly 2.5 billion dollars. ${ }^{13}$ As a matter of arithmetic then, the Fed simply did not have enough securities to absorb the entire volume of excess reserves with open market sales.

Furthermore, from the Fed's point of view, there was no guarantee that excess reserves would not continue to grow, necessitating further security sales. During this period the Fed did, not have complete control of base money since the United States was on a gold standard. The size of the Fed's portfolio had been virtually held constant from 1934 until the end of the decade but large gold inflows had financed the increase in excess reserves. Even if the Fed had desired to absorb only a portion of excess reserve growth with open market sales, continuing gold inflow could have eventually exhausted the Fed's portfolio. For these reasons reserve requirements, and specifically the power to raise them, did play a useful role in the Fed's effort to immobilize excess reserves in this period.

In summary, the role played by reserve requirements in Fed credit policy in the interwar period varied greatly. From the early years of the Federal Reserve System through the 1920s the Fed relied on the discount rate as its primary policy instrument. Credit conditions were managed by manipulating the discount rate ; but credit, money, and reserve demand were essentially accommodated at a given discount rate so that reserve requirements did not effectively restrain credit expansion during those years. As pointed out by the 1931 Fed Committee on Bank Reserves, reserve requirements did not function well to restrain credit expansion during the stock market boom of 1928-29. In the 1930s credit demand was low, excess reserves were extremely large, and required reserves were not then important as a constraint on credit expansion. However, reserve requirements, specifically reserve requirement increases, were useful in the Fed's effort to immobilize excess reserves which it then regarded as excessive.

of an emergency due to credit expansion. The Banking Act of 1935 removed the need for Presidential approval but limited reserve requirement changes to the range between their existing level and twice that level. See Board of Governors [12], p. 960.

${ }^{13}$ Board of Governors [6] 1936, p. 74. 
From 1942 until the Treasury-Federal Reserve Accord of 1951 the Fed's credit policy became a strict bond price support program. By supporting the price of government bonds, i.e., holding interest rates down, the Fed used its money-creating power to help finance wartime needs. Under the bond price support program the Fed simply bought eligible government securities offered to it at the pegged price. Since the policy was deliberately accommodative, reserve requirements did not function at all during this period to restrain credit expansion.

\section{Monetary Control}

Federal Reserve policy statements in the 1950s shifted from almost exclusive concern with credit conditions to inclusion of the money stock as a relevant criterion for policy. ${ }^{14}$ Since then the monetary aggregates have become increasingly important as guides to policy and by the late 1970s M1 became the primary intermediate policy target. Increasing concern for the monetary aggregates during this period has been accompanied by a widespread belief that reserve requirements have been useful for monetary control. Reserve requirements can contribute significantly to monetary control, but only under certain conditions. As explained below, these conditions have never been entirely met in practice.

The belief that reserve requirements are useful for monetary control is generally based on the "money multiplier" model of money stock determination. ${ }^{15}$ The money multiplier is essentially a relationship between deposits (D) and reserves (R), $D=m R$, where $\mathrm{m}$ is called the money multiplier. If banks keep excess reserves, i.e., reserves held in excess of legal requirements, to a minimum and reserve requirments are uniformly and solely applied to deposits, then the multiplier can be essentially constant. In this case the Fed can exercise close control of deposit volume through close control of reserves. Reserve requirements are important in this method of monetary control because they make the multiplier more stable.

An additional condition, frequently either taken for granted or overlooked, is necessary for money stock determination to work as described above. The Fed must maintain control of reserves. If the volume of reserves is determined by banking system demand then reserve requirements do not constrain monetary expansion. Reserve demand is simply accommodated and required reserves serve only to enlarge the de-

${ }^{14}$ Friedman and Schwartz [28], pp. 627-32 document this shift and describe it as a "near-revolutionary change."

${ }^{15}$ For a more detailed discussion of the money multiplier see Goodfriend [30]. mand for reserves at any given level of deposits. In this case, the stock of deposits is determined independently of reserve requirements.

In practice, the Fed has never adopted operating procedures designed to control reserves in order to use the money multiplier relationship to control deposits. Throughout much of the 1950s and 1960s free reserve targeting was used in conjunction with discount rate adjustments to execute monetary policy. ${ }^{16}$ Restraint was achieved by lowering the target for free reserves and raising the discount rate ; expansion was encouraged by raising the free reserve target and lowering the discount rate. Free reserves and the discount rate fell into disuse in the early 1970 s as operating variables. At that time, the Federal funds rate emerged as the primary policy instrument. Monetary control was exercised with the funds rate instrument by raising the rate to restrain money growth and lowering it when more rapid money growth was desired.

Operating procedures utilizing free reserves and the discount rate on one hand or the Federal funds rate on the other are essentially accommodative. They operate, as did the discount rate operating procedure of the 1920s, by influencing the general level of short-term interest rates in order to affect the quantity of money and credit demanded. ${ }^{17} \mathrm{With}$ these operating procedures, reserves are merely supplied as required to support the quantity of money and credit demanded given the operating target. A 1971 Federal Reserve Board Staff Study acknowledged the accommodative nature of these operating procedures :

The operating emphasis on money market conditions has meant that the [Fed] was essentially accommodative, in the sense that market demands for credit and money would be accommodated at a given Federal funds rate or level of net borrowed or net free reserves?

Since both the free reserve/discount rate and Federal funds rate operating procedures are accommodative,

\footnotetext{
${ }^{16}$ Free reserves are defined as excess reserves minus borrowed reserves, or equivalently nonborrowed reserves minus required reserves. Net borrowed reserves are negative free reserves. For a Federal Reserve view of free reserves as an operating target see Federal Reserve Bank of New York [26].

${ }^{17}$ Details of the free reserve/discount rate, Federal funds rate, and discount rate operating procedures can be in vestigated within the framework developed by Goodfriend [30]. See McCallum [35] for an analysis of the feasibility of an interest rate policy rule under rational expectations. Friedman and Schwartz [28], pp. 615-16 and Meigs [36] point out the accommodative nature of free reserve targeting. Friedman and Schwartz [28], p. 223 make a similar point about the discount rate operating procedure of the $1920 \mathrm{~s}$.
}

${ }^{18}$ Axilrod [2], p. 6. 
reserve requirements did not exercise an effective constraint on monetary expansion during the postAccord period in which these operating procedures were utilized. ${ }^{19}$

In October 1979, the Fed adopted a nonborrowed reserve operating procedure. The move to nonborrowed reserves could have given reserve requirements a significant role in controlling money if reserve requirements had been contemporaneous. ${ }^{20}$ However, reserve requirements have been computed on a lagged basis since September 1968. With a nonborrowed reserve instrument and lagged reserve requirements, the Fed's operating target within a reserve statement week has essentially been net borrowed reserves, i.e., negative free reserves. To see this, recall that net borrowed reserves equals the difference between required reserves and nonborrowed reserves. With a nonborrowed reserve instrument the Fed supplies a predetermined volume of nonborrowed reserves each reserve statement week; and under lagged reserve requirements required reserves are known at the beginning of each reserve statement week. Therefore, operating with a nonborrowed reserve instrument and lagged reserve requirements amounts to targeting net borrowed reserves in any given reserve statement week. As pointed out above, net borrowed or free reserve targeting is accommodative; so even after the adoption of a nonborrowed reserve instrument in 1979, reserve requirements still do not exercise an effective constraint on monetary expansion. ${ }^{21}$

While it is true that net borrowed reserve and nonborrowed reserve targeting with lagged reserve

\footnotetext{
${ }^{19}$ It has been argued that even though reserve demand has been accommodated, the effectiveness of the funds rate operating procedure may have been enhanced by the imposition of reserve requirements on transaction deposits in the following sense: For targeting transaction balances, if the implicit own rate on transaction deposits was competitively determined, then noninterest-earning reserve requirements on transaction deposits increased the sensitivity to the level of market rates of the rate spread between transaction deposits and alternative instruments paying a market rate, allowing manipulation of the funds rate instrument to more readily influence the quantity of transaction balances demanded. However, although the implicit own rate on transaction deposits may have moved over time with the general level of interest rates, for the most part it probably has not moved competitively in immediate response to the level of market rates. The spread between rates on transaction deposits and alternative instruments paying a market rate has therefore likely moved with the level of interest rates apart from the imposition of reserve requirements on transaction deposits.

${ }^{20}$ See Goodfriend [30] for a discussion of monetary control with a nonborrowed reserve instrument and contemporaneous reserve requirements.

${ }^{21}$ Goodfriend [31] explains why with lagged reserve requirements, a Federal funds rate instrument can provide better monetary control than a nonborrowed reserve
} instrument. requirements are identical within a reserve statement week, they are different in their dynamic response to money stock targeting error, i.e., deviations of the money stock from target, in the following sense. If, for example, the money stock comes in above target in a given reserve statement week, then two weeks later, given an unchanged nonborrowed reserve path, the banking system is forced to obtain additional required reserves at the discount window. Given the nonprice rationing at the discount window, additional discount window borrowing raises the Federal funds rate (for a given discount rate) and thereby tends to bring the money stock back to target. By contrast, with a predetermined net borrowed rather than nonborrowed reserve path, no automatic mechanism exists to bring the money stock back to target.

In short, nonborrowed reserve targeting with lagged reserve requirements utilizes a feedback rule to automatically adjust the weekly net borrowed reserve path in response to money stock targeting error. In its pure form, the rule feeds changes in required reserve demand due to money stock targeting error dollar for dollar into net borrowed reserves. But in spite of the fact that the feedback rule is expressed in terms of required reserves, actual imposition of reserve requirements on deposits is not essential to the implementation of the feedback rule. As explained above, the feedback rule is a mechanism designed to produce a particular Federal funds rate movement in response to money stock targeting error. Under lagged reserve requirements the Federal funds rate response based on reserve requirements is delayed two weeks. But by that time, the Fed itself already has an observation on the twoweek-old money stock targeting error. This means that the Fed can base feedback to the Federal funds rate directly on measured two-week-old money stock targeting error. ${ }^{22}$ In other words, the dynamic response to money stock targeting error under the current nonborrowed reserve-lagged reserve requirements monetary control procedure could be duplicated without imposition of reserve requirements.

In 1980 Congress passed the Monetary Control

\footnotetext{
${ }^{22}$ In practice, substantial and frequent adjustment of the discount rate has been utilized to augment or offset the automatic interest rate response to money stock targeting error described in the text. The post-October 1979 operating procedure, utilizing net borrowed reserve targeting and discount rate adjustments, resembles the free reserve/discount rate operating procedure utilized in the $1950 \mathrm{~s}$ and $1960 \mathrm{~s}$ and also, to a large extent, the discount rate operating procedure of the $1920 \mathrm{~s}$. The post-October 1979 operating procedure differs from the others to the extent that it employs an automatic mechanism for adjusting the net borrowed reserve target in response to money stock targeting error. Goodfriend [29] discusses some shortcomings of this automatic adjustment mechanism as it has been employed.
} 
Act (MCA) which extensively reformed the structure of reserve requirements. This legislation grew out of several years of proposals and debates on the problem of Fed membership attrition. The Fed's share of banks had dropped approximately from 50 percent in 1950 to 40 percent in 1976, and member banks' share of gross deposits had fallen approximately from 86 percent to 74 percent in the same period, with the loss of members and deposits apparently accelerating. ${ }^{23}$ The cost of membership was primarily due to the Fed's noninterest-earning reserve requirement which put member banks at a competitive disadvantage relative to nonmembers who generally had lower reserve requirements and were allowed to hold interest-earning assets as reserves. ${ }^{24}$ This disadvantage had increased over the previous two decades with the rise in inflation and interest rates.

The Fed argued that its ability to control the monetary aggregates was weakening as deposits moved outside its reserve requirement jurisdiction. ${ }^{25}$ The solution adopted by Congress in the MCA was to make reserve requirements universal, that is, to require all depository institutions, whether members of the Federal Reserve System or not, to hold reserves in accordance with Fed requirements. In addition, reserve requirements were made more uniform. ${ }^{26}$ These are the reforms in the MCA which are meant to improve monetary control. It should be noted, however, in light of the discussion above, that the structure of reserve requirements has been basically irrelevant to monetary control as carried

${ }^{23}$ "The Burden of Federal Reserve Membership . . ." [16], pp. 2-3.

${ }^{24}$ See Federal Reserve Committee on Branch. Group, and Chain Banking [27]; Wingfield [68]; White [66], pp. 5-9; and Benston [5], Chapter III, for discussions of the costs and benefits of Federal Reserve membership.

"The Burden of Federal Reserve Membership ...." [161,

Appendix A, contains a detailed discussion of nonmember bank reserve requirements.

${ }^{25}$ See for example, testimony by Chairmen of the Federal Reserve Board: Arthur F. Burns in U. S. Congress, Senate [61], p. 35; G. William Miller in U. S. Congress, House [52], pp. 96-98 and in U. S. Congress, Senate [60], pp. 17, 21-22; and Paul A. Volcker in U. S. Congress, Senate [58], pp. 8-10, 35 .

${ }^{26}$ The Monetary Control Act of 1980 requires depository institutions, after a gradual phase-in period, to maintain a reserve equal to:

i) 3 percent of the first 25 million dollars of total transaction accounts.

ii) 12 percent-or in the range of 8-14 percent as the Board may prescribe-of transaction accounts in excess of 25 million dollars.

iii) 3 percent-or in the range of $0-9$ percent as the Board may prescribe-of nonpersonal time deposits.

See Board of Governors [10] for a summary of the MCA, and Board of Governors [15], Regulation D. out with the post-October 1979 nonborrowed reservelagged reserve requirements operating procedure. Recently, the Federal Reserve Board announced its intention to return to contemporaneous reserve requirements. This commitment is an important first step toward a reserve-based operating procedure in which the reserve requirement reforms embodied in the MCA could significantly improve monetary contro $1 .^{27}$

\section{III.}

\section{FINANCING CONSIDERATIONS AND RESERVE REQUIREMENT LEGISLATION}

The preceding discussion explained that reserve requirements have rarely functioned as indicated in the standard rationales. On the other hand, reserve requirements have consistently functioned to help finance the United States Treasury. Furthermore, financing considerations have substantially influenced reserve requirement legislation throughout the history of the Federal Reserve System.

The first part of this section explains that reserve requirement reform in the early years of the Federal Reserve System was largely designed to enhance the Fed's power to create base money in order to provide reserves to the banking system through the rediscount mechanism, to meet its own financial needs, and to finance United States participation in World War I. The second part describes the origin and development of the systematic transfer of net Fed earnings to the Treasury. Lastly, this section covers recent reserve requirement reform, focusing on concern for the Fed membership problem and the influence of Treasury revenue considerations in the drafting of the Monetary Control Act of 1980.

\section{Early Reserve Requirement Reform Under the Federal Reserve System}

One of the major features of the reorganization of the banking system under the Federal Reserve Act was the requirement that member banks hold required reserves in the form of deposits with Federal Reserve Banks. As mentioned above, the rule that member banks hold required reserves as vault cash or with Federal Reserve Banks was designed to eliminate pyramiding. More importantly for the issue at hand, the requirement centralized gold reserves in the Federal Reserve Banks. The first installment of the initial transfer of member bank reserves to the

\footnotetext{
${ }^{27}$ Goodfriend [30, 31] describes how a move to contemporaneous reserve requirements could improve monetary control.
} 
Reserve Banks consisted entirely of lawful money (gold or money that the Treasury would exchange for gold). At least one-half of each subsequent transfer was in lawful money; the rest was receivable in certain eligible paper. $^{28}$

The Reserve Banks themselves were initially required to keep a 35 percent reserve in lawful money against deposits and a 40 percent reserve against Federal Reserve notes. The fact that the initial transfer of member bank reserves to the Reserve Banks averaged more than 50 percent lawful money meant that the volume of deposit and note liabilities which the Reserve Banks could create was not initially constrained by their lawful money reserve requirement. ${ }^{29}$ The centralization of gold reserves in the Reserve Banks, together with their initially ineffective reserve requirement constraint and the power to rediscount or purchase securities, gave the Federal Reserve System the power to create additional deposit or note liabilities, i.e., base money, in exchange for earning assets. As mentioned earlier, the power to provide reserves to the banking system, particularly in times of stress, was viewed as a much needed provision of the Federal Reserve Act.

\footnotetext{
${ }^{28}$ Section 19 of the Federal Reserve Act of 1913 directed member banks to make an initial transfer of a portion of their required reserves to the Reserve Banks at the time of the establishment of the Reserve Banks. Three subsequent installments were to be made at six-month intervals starting twelve months after the first installment. Section 19 also specified that no more than half of each installment was to consist of eligible paper; the rest was receivable in gold or lawful money. See "Federal Reserve Act of 1913" [24]. p. 40. This provision appears to have been superseded by Federal Reserve Board Circular No. 10 of October 28, 1914 which directed that the first installment, due November 16, 1914, be made entirely in gold or lawful money. See Board of Governors [6] 1914, p. 167. Subsequent installments were made on November 16, 1915; May 16, 1916; and November 16, 1916. The Board of Governors Annual Report 1916 incorrectly reports an installment as having been made on May 16, 1915. See Board of Governors [6] 1916, p. 22 and Commercial and Financial Chronicle [19] November 6, 191.5, p. 1515. Federal Reserve Board notices prior to the second and fourth installments reiterated that no more than half of each installment was receivable in eligible paper. See Board of Governors [11] November 1915, p. 361 and November 1916, pp. 597-98.

${ }^{29}$ The only time that Reserve Bank lawful money reserve requirements were allowed to seriously constrain Federal Reserve credit expansion was in the period immediately following World War I. See Friedman and Schwartz [28], pp.229-31. The next time that Reserve Bank reserve requirements threatened to constrain the expansion of Federal Reserve credit, during World War II, they were reduced to 25 percent on both Reserve Bank deposit and note liabilities. Finally, the last time that Reserve Bank reserve requirements threatened to constrain Fed credit expansion, this time in the mid1960 s, they were reduced to zero. See Board of Governors [8], pp. 328-29 and [9], pp. 464-65. Reserve Bank reserve requirements were reduced first to enable the Fed to continue to expand credit and help finance U. S. participation in World War II, and finally to make gold available to help finance the U. S. balance of payments deficit without constraining Fed credit expansion.
}

It should be noted, however, that it was not technically necessary that member banks hold reserves in the form of deposits at Reserve Banks either to eliminate pyramiding or to give the Fed power to create base money. Pyramiding could have been largely eliminated by simply mandating that banks hold required reserves in their own vaults, though pyramiding of voluntary correspondent balances might have been greater in the absence of correspondent services available at the Fed. Furthermore, availability of reserves at the Fed discount window alone could have remedied monetary problems stemming from pyramiding and for that matter could also in principle have vitiated any liquidity rationale for reserve requirements. ${ }^{30}$ Reserve Banks could have been given the power to rediscount or purchase securities without having to hold member bank reserves, although the gold reserve acquired by the Reserve Banks was probably useful in giving the appearance of adhering to conventional banking practice. However, reserve requirements on member bank deposits were not even necessary for the Fed to acquire gold, since Reserve Banks could in principle have acquired gold by offering attractive interest rates on deposits.

At any rate, initially the Fed's power to create base money and acquire earning assets was primarily useful to the Fed itself. The advantages to the Fed were twofold. First, income from a portfolio. of securities made the Reserve Banks financially selfsufficient. Second, possession of a portfolio of securities allowed the Reserve Banks to more effectively influence or stabilize the money market. These objectives were acknowledged in the Federal Reserve Board's Annual Report of 1914:

The Reserve Banks have expenses to meet, and while it would be a mistake to regard them merely as profit-making concerns and to apply to them the ordinary test of business success. there is no reason why they should not earn their expenses, and a fair profit besides, without failing to exercise their proper functions and exceeding the bounds of prudence in their management. Moreover, the Reserve Banks can never become the leading and important factor in the money market which they were designed to be unless a considerable portion of their resources is regularly and constantly employed?

The first reserve requirement reform following the Federal Reserve Act was made in 1917. The 1917 reform amended the Federal Reserve Act to specify that vault cash could no longer count as required reserves. This provision by itself would have raised

\footnotetext{
${ }^{30}$ Related issues are discussed in Sargent and Wallace [43].

${ }^{31}$ Board of Governors [6] 1914, p. 18.
} 
total reserve demand since banks still needed to hold vault cash, but the reform also significantly lowered reserve requirements, making it more acceptable to member banks. ${ }^{32}$ The main purpose of the 1917 reform was to further concentrate gold at Reserve Banks by removing the incentive for member banks to hold gold as vault cash. Prior to 1917, vault cash could be used to partially satisfy reserve requirements. However, neither Federal Reserve notes nor National Bank notes could be counted as required reserves. As a result, a large portion of the country's gold holdings was absorbed in the form of vault cash at member banks. The concentration of gold at the Fed was undertaken to ensure that Reserve Bank gold reserves would not constrain the Fed's ability to accommodate the large demands for credit expected to arise out of the country's entry into World War $\mathrm{I}^{33}$

As it turned out, United States participation in World War I and the large Federal deficits that accompanied it did precipitate the first major use of the Fed's power to create base money. Though most of the Federal deficit was covered by sales of U. S. bonds to banks and the public, the Reserve Banks held interest rates down by keeping their discount rates low and accommodating credit demand at these rates. In this sense, the Fed used its money-creating power to help finance bank, public, and Treasury credit needs in World War I.

\section{Fed-Treasury Transfers}

The power to purchase and rediscount securities in exchange for its own noninterest-earning liabilities gave the Fed a means of earning substantial income. During the drafting of the Federal Reserve Act it was recognized that this income would generally exceed operating expenses and payment of dividends to "stockholders." ${ }^{34}$ Accordingly, Section 7 of the Federal Reserve Act specified how net earnings were to be distributed. Specifically, Congress directed the Fed to pay the Treasury a "franchise tax" equal to

\footnotetext{
${ }^{32}$ Reserve requirements were reduced to 13,10 , and 7 percent on demand deposits for central reserve city, reserve city, and country member banks respectively, and to 3 percent on time deposits at all member banks. See Board of Governors [12], p. 959; also see Cagan [17], p. 190.

${ }^{33}$ For Federal Reserve statements of the motivation for the legislation see Board of Governors [6] 1917, pp. 11-12 and [11] July 1917, pp. 508-9.

${ }^{34}$ Reserve Bank stock is merely a required payment to a Reserve Bank that goes with Federal Reserve membership. Although Reserve Bank stock pays a fixed 6 percent dividend, it carries with it virtually none of the responsibilities and entitlements of commercial stock issue. See Federal Reserve Act as Amended . . . [23], Sections 2, 5, and 7.
}

one-half of net earnings after expenses and payment of dividends. The other half of net earnings was to be paid into a surplus fund until it equaled 40 percent of paid-in capital stock at the Reserve Banks. ${ }^{35}$ After surplus reached 40 percent of paid-in capital, net earnings were to go entirely to the Treasury. The reasoning behind the franchise tax can be found in the House Report on the Federal Reserve Act which says :

it is obvious that the function of note issue will result in a large volume of earnings which the Federal reserve banks could not enjoy were they to share this power with other banking institutions. To a substantial share in this earning, leaving for the reserve banks only a fair compensation for their services in taking out. the notes, the public is evidently entitled.

Legislators also recognized that requiring member banks to hold noninterest-earning reserves at Federal Reserve Banks would provide an additional source of earnings for the Fed. The question of whether or not to pay interest on required reserves at the Fed was discussed during the drafting of the Federal Reserve Act. ${ }^{37}$ Ultimately, the Federal Reserve Act itself was silent on this issue, though the Senate Report on the Act says that "reserves piked with the Federal reserve banks would not bear interest under the present bill (although this may possibly be found expedient at some future time when the system is established). ${ }^{638}$

Legislation passed in 1919 amended Section 7 to require that all net earnings be added to surplus until it amounted to 100 percent of subscribed capital (which is twice paid-in capital) after which 10 percent of net earnings was to be added to surplus and 90 percent paid as a franchise tax..$^{39}$ The surplus deemed appropriate was thereby quintupled as measured relative to paid-in capital just a few years after

\footnotetext{
${ }^{35}$ Surplus is employed in commercial enterprises as a reserve for contingencies such as absorbing losses or meeting expense's and dividends when earnings are low. Board of Governors [8], p. 356 lists charges against Federal Reserve Bank surplus from 1914 through 1941. Board of Governors [9], p. 501 and [7], pp. 450-69 provide less detailed information on the disposition of surplus from 1942 to 1979. More information on the disposition of surplus may be found in various Board of Governors Annual Reports. Although it is not clear how the level of surplus deemed appropriate for the Reserve Banks was determined. or why the Fed. with its power to create money, was expected to need surplus at all, maintaining surplus held as securities has enabled the Fed to meet contingencies without affecting the stock of base money.

${ }^{36}$ U. S. Congress, House [48], p. 39.

${ }^{37}$ See, for example, Congressional Record [21] Part 1 , pp. 451-54 and Part 17, p. 562.

${ }^{33}$ U. S. Congress, Senate [54], p. 12.

${ }^{39}$ See U. S. Congress, Senate [55], p. 18.
} 
the Federal Reserve Act was passed. The House Report on the 1919 amendment says that this was necessary because the large expansion of Federal Reserve credit during World War I warranted a larger surplus to give the Reserve Banks added strength. Wartime credit expansion did enormously increase member bank assets, liabilities, and reserve balances at the Fed. But it also correspondingly raised member bank capital structure, and the requirement that each member bank's subscription to Reserve Bank capital stock be maintained at 6 percent of its own capital stock meant that increased member bank reserves at the Fed would be accompanied by a proportionate increase in paid-in and surplus capital.

However, as a result of an increase in the demand for Federal Reserve notes as currency and, to some extent, the exchange of Federal Reserve notes for gold certificates during the war, capital fell from 5.8 percent of total Reserve Bank liabilities at the end of 1914 to 2 percent at the end of $1918 .{ }^{40}$ Quintupling the ratio of surplus to paid-in capital roughly restored the 1914 ratio of capital to total Reserve Bank liabilities. Reserve Bank portfolios and earnings had grown so large as a result of discount policy during World War I that some Reserve Banks were immediately able to raise surplus to 100 percent of subscribed capital, and the Fed transferred 3 million dollars to the Treasury in 1919. Transfers to the Treasury during the following two years were in the neighborhood of 60 million dollars, the largest by far until after World War II.

As the table indicates, Fed-Treasury transfers have continued almost without. interruption, though under varying labels, to this day. ${ }^{41}$ Transfers were made under the franchise tax designation from 1914 until 1932. Congress abolished the franchise tax in the Banking Act of 1933. That legislation also created the Federal Deposit Insurance Corporation (FDIC) and required the Reserve Banks to subscribe an amount equal to one-half their accumulated surplus, 139 million dollars, for FDIC stock. ${ }^{42}$ As compensation, the Reserve Banks were allowed to retain all subsequent net earnings to rebuild surplus. However, transfers to the Treasury were partially re-

\footnotetext{
${ }^{40}$ See Board of Governors [8], pp. 330, 409; and Willis [67], p. 1440.

${ }^{41}$ Barro [4] discusses and measures Fed revenue from money creation. Note that his tables report gross while ours reports net revenue. For more detail on the sources and uses of Fed earnings see Board of Governors [8], p. 356; [9], p. 501; and [7], pp. 450-69. See Auernheimer [1] and references contained therein for theoretical discussions of the revenue from money creation.

${ }^{42}$ Board of Governors [6] 1947, pp. 83-84.
}

sumed in 1935 under a newly created Section 13b of the Federal Reserve Act which permitted the Reserve Banks to make "industrial" loans. Fed-Treasury transfers under Section 13b were relatively insignificant and transfers under that designation were terminated in October 1947. ${ }^{43}$

Larger Fed-Treasury transfers were resumed in 1947 under the so-called "interest on Federal Reserve notes" designation. The events that led to this means of Fed-Treasury transfers are as follows. Although the World War II bond price support program remained essentially in effect until the, 1951 Accord, the Fed favored higher Treasury bill interest rates after the war in order to help restrain credit expansion. The problem from the Fed's point of view was clearly summarized by Federal Reserve Board Chairman Eccles in an April 1947 meeting of the Federal Open Market Committee (FOMC):

Chairman Eccles stated that he had come to the conclusion that, if any progress was to be made with the Treasury in getting an agreement. to discontinue the posted rate on Treasury bills and to permit the bifl rate to rise to a level which would be determined by the market in line with the $7 / 8$ percent rate on certificates, it would be necessary to present to the Treasury a program pursuant to which the increased cost of Treasury financing that might result from the changed bill program would be offset by paying into the Treasury a substantial portion of the net earnings of the Reserve Banks. He thought that the Treasury would not be willing to agree now to eliminate the posted rate on the basis of the introduction and passage of legislation to restore the franchise tax which probably would require a number of months, and that therefore the Board of Governors should immediately prescribe an interest rate on Federal Reserve notes under the provisions of the fourth paragraph of Section 16 of the Federal Reserve Act, the first payment to be made to the Treasury in April on Federal Reserve notes outstanding during the first quarter of the year. If this were done, he said, then the Treasury could agree to a higher rate on Treasury bills with the assurance that the increased interest, cost would be returned to the Treasury in the form of interest payments on Federal Reserve notes. ${ }^{44}$

At the same meeting Allan Sproul, President of the Federal Reserve Bank of New York, stated that:

in his opinion the primary purpose of the [Board's] authority to impose an interest. charge on Federal Reserve notes uncovered by gold was the belief that this authority could be used to restrict the circulation of such notes and thus to restrain inflationary tendencies and there was a real question as to whether Congress intended the authority to be used in the manner proposed.45

However, he went on to say that:

${ }^{43}$ See Hackley [32], pp. 133-45 for a discussion of Section 13b; also see Board of Governors [6] 1947, pp. 83-84.

${ }^{44}$ Board of Governors [14] 1947, 4/1/47, p. 69.

${ }^{45}$ Ibid., p. 74 . 
FED-TREASURY TRANSFERS

\begin{tabular}{|c|c|c|c|}
\hline Year & $\begin{array}{l}\text { Fed Payments to } \\
\text { U.S. Treasury* } \\
\text { (\$ billions) }\end{array}$ & $\begin{array}{c}\text { Federal } \\
\text { Government } \\
\text { Receipts** } \\
\text { (\$ billions) }\end{array}$ & $\begin{array}{c}\text { Fed Payments } \\
\text { as a Percent } \\
\text { of Federal } \\
\text { Government } \\
\text { Receipts }\end{array}$ \\
\hline $\begin{array}{r}1917 \\
18 \\
19\end{array}$ & $\begin{array}{c}.001 \\
- \\
.003\end{array}$ & & \\
\hline $\begin{array}{r}1920 \\
21 \\
22 \\
23 \\
24 \\
25 \\
26 \\
27 \\
28 \\
29\end{array}$ & $\begin{array}{l}.061 \\
.060 \\
.011 \\
.004 \\
.0001 \\
.00006 \\
.0008 \\
.0002 \\
.003 \\
.004\end{array}$ & 3.804 & .105 \\
\hline $\begin{array}{r}1930 \\
31 \\
32 \\
33 \\
34 \\
35 \\
36 \\
37 \\
38 \\
39\end{array}$ & $\begin{array}{c}.00002 \\
- \\
.002 \\
- \\
- \\
.0003 \\
.0002 \\
.0002 \\
.0001 \\
.00002\end{array}$ & $\begin{array}{l}3.047 \\
2.047 \\
1.708 \\
2.670 \\
3.541 \\
3.964 \\
5.024 \\
7.039 \\
6.480 \\
6.721\end{array}$ & $\begin{array}{c}.0007 \\
- \\
.117 \\
- \\
- \\
.008 \\
.004 \\
.003 \\
.002 \\
.0003\end{array}$ \\
\hline $\begin{array}{r}1940 \\
41 \\
42 \\
43 \\
44 \\
45 \\
46 \\
47 \\
48 \\
49\end{array}$ & $\begin{array}{l}.00008 \\
.0001 \\
.0002 \\
.0002 \\
.0003 \\
.0002 \\
.00007 \\
.075 \\
.167 \\
.193\end{array}$ & $\begin{array}{r}8.641 \\
15.420 \\
22.943 \\
39.258 \\
41.008 \\
42.495 \\
39.105 \\
43.220 \\
43.218 \\
38.706\end{array}$ & $\begin{array}{l}.0009 \\
.0006 \\
.0009 \\
.0005 \\
.0007 \\
.0005 \\
.0002 \\
.174 \\
.386 \\
.499\end{array}$ \\
\hline $\begin{array}{r}1950 \\
51 \\
52 \\
53 \\
54 \\
55 \\
56 \\
57 \\
58 \\
59\end{array}$ & $\begin{array}{l}.197 \\
.255 \\
.292 \\
.343 \\
.276 \\
.252 \\
.402 \\
.543 \\
.524 \\
.911\end{array}$ & $\begin{array}{l}50.035 \\
64.277 \\
67.317 \\
70.032 \\
63.738 \\
72.559 \\
77.985 \\
81.906 \\
78.662 \\
89.826\end{array}$ & $\begin{array}{l}.394 \\
.397 \\
.434 \\
.490 \\
.433 \\
.347 \\
.515 \\
.663 \\
.666 \\
1.014\end{array}$ \\
\hline $\begin{array}{r}1960 \\
61 \\
62 \\
63 \\
64 \\
65 \\
66 \\
67 \\
68 \\
69\end{array}$ & $\begin{array}{l}.897 \\
.687 \\
.799 \\
.880 \\
1.582 \\
1.297 \\
1.649 \\
1.907 \\
2.464 \\
3.019\end{array}$ & $\begin{array}{r}96.141 \\
98.058 \\
106.187 \\
114.415 \\
114.913 \\
124.337 \\
141.843 \\
150.496 \\
174.442 \\
196.858\end{array}$ & $\begin{array}{l}.933 \\
.701 \\
.752 \\
.769 \\
1.377 \\
1.043 \\
1.163 \\
1.267 \\
1.413 \\
1.534\end{array}$ \\
\hline $\begin{array}{r}1970 \\
71 \\
72 \\
73 \\
74 \\
75 \\
76 \\
77 \\
78 \\
79\end{array}$ & $\begin{array}{l}3.494 \\
3.357 \\
3.231 \\
4.341 \\
5.550 \\
5.382 \\
5.870 \\
5.937 \\
7.006 \\
9.279\end{array}$ & $\begin{array}{l}191.871 \\
198.554 \\
227.505 \\
258.640 \\
287.821 \\
287.335 \\
331.750 \\
375.210 \\
431.569 \\
493.636\end{array}$ & $\begin{array}{l}1.821 \\
1.691 \\
1.420 \\
1.678 \\
1.928 \\
1.873 \\
1.769 \\
1.582 \\
1.623 \\
1.880\end{array}$ \\
\hline $\begin{array}{r}1980 \\
81\end{array}$ & $\begin{array}{l}11.706 \\
14.024\end{array}$ & $\begin{array}{l}540.722 \\
628.219\end{array}$ & $\begin{array}{l}2.165 \\
2.232\end{array}$ \\
\hline
\end{tabular}

$\ldots$ if the alternative of a restoration of the franchise tax would mean extended delay and prevent effective negotiation with the Treasury with respect to the elimination of the posted rate on Treasury bills and eventually some change in short-term interest rates, he would have to go along with the proposal for the establishment of the interest charge. He felt that action with respect to the restoration of some measure of control over bank credit at this time was more important than the means to be used in siphoning some of the earnings of the Federal Reserve Banks into the Treasury. ...

The plan proposed by Chairman Eccles was acceptable to the Treasury, and on April 24, 1947 the Federal Reserve Board, acknowledging that by the end of 1946 the combined surplus of the Reserve Banks exceeded subscribed capital, announced its decision to levy an interest charge on Federal Reserve notes issued by Reserve Banks to pay into the Treasury approximately 90 percent of Reserve Bank net earnings. ${ }^{47}$ The FOMC announced termination of the fixed rate on Treasury bills two months later. ${ }^{48}$

The Federal Reserve Board's voluntary continuance of Fed-Treasury transfers under the "interest on Federal Reserve notes" designation in effect operated like the legislated franchise tax rule prior to 1933. Like the franchise tax rule, the rule for FedTreasury transfers under the "interest on Federal Reserve notes" designation. placed no ceiling on accumulated surplus. Within a few years this became a problem for the Fed. Questions about the appropriate level of surplus were raised in hearings on the Financial Institutions Act of 1957; and the Board was aware of a staff recommendation at the Bureau of the Budget that would transfer to the Treasury

${ }^{46}$ Ibid., p. 75.

${ }^{47}$ Board of Governors [6] 1947, pp. 83-84.

${ }^{48}$ Ibid., pp. 91-94. See Stein [46]: Chapter 10, for a good discussion of Fed-Treasury relations during this period.

Note: Figures rounded to millions where possible, otherwise taken to first significant digit.

* From 1914 to 1932 the Federal Reserve Banks were subject to a "franchise tax" on net earnings under Section 7 of the Federal Reserve Act. Payments to the Treasury were made under this designation each year with the exception of 1914-1916 and 1931, when Reserve Bank earnings were not sufficient to meet dividend payments as well as expenses. Tax payments were temporarily suspended in 1918 pending legislation passed in 1919 concerning the disposition of Reserve Bank net earnings. As a result of the suspension of the franchise tax in the Banking Act of 1933, no payments were made in 1933 and 1934. From 1935 to 1947 payments were made under Section $13 \mathrm{~b}$ of the Federal Reserve Act. In 1947 the Federal Reserve Board initiated payments to the Treasury in the form of "interest on Federal Reserve notes." Payments have continued to the present under this designation.

** Not available by calendar year prior to 1929

Sources: Board of Governors [6] 1981, Table 7, and [6] 1931, pp. 15-16; U. S. Department of Commerce, Bureau of Economic Analysis [62], Table 3.2, and [63], Table 3.2; and U.S. Congress, Senate [55], pp. 17-19. 
all Reserve Bank surplus funds. ${ }^{49}$ Finally, the Federal budget deficit for fiscal year 1959 was about 13 billion dollars, roughly three times larger than any previous peacetime deficit. As a result, pressure on the Fed to take further action on surplus and FedTreasury. transfers mounted in the second half of 1959.

The 1959 Congressional session ended without acting on the matter and Federal Reserve Board Chairman Martin expressed the hope that the Fed would have a proposed solution to the problem before the next session. ${ }^{50}$ As mentioned above, it was difficult to justify any particular level of Reserve Bank surplus as appropriate. Consequently, the Fed's proposal appealed to the principle that Congress itself had established in the 1919 amendment to the Federal Reserve Act. On this basis, the Federal Reserve Board announced in December 1959 its decision to maintain surplus at 100 percent of subscribed capital, to immediately transfer to the Treasury all surplus currently in excess. of that amount, and to transfer to the Treasury 100 percent of net earnings after maintaining surplus at the level of subscribed capital thereafter. $^{51}$

The 1959 Fed action on surplus did not satisfy Congress and the Treasury for long. Except for a slight budget surplus in 1960, the next five years saw a string of large peacetime Federal budget deficits cumulating to over 20 billion dollars by the end of fiscal year 1964. In 1964, legislation considered by Congress threatened to limit the Fed's independence in order to use the Fed's moneycreating power to help finance the large deficits. ${ }^{52}$ Meanwhile, because of growth in member bank assets and liabilities, corresponding growth in member bank capital structure, and the requirement that member banks subscribe to Reserve Bank capital stock an amount equal to 6 percent of their own capital, the subscribed capital of the Reserve Banks rose by over 35 percent from the end of 1959 to the end of $1964 .^{53}$ As a result, pressure to reduce the Fed's surplus grew both because a reduction in surplus would provide a sizable immediate lump-sum payment to the Treasury and because maintaining surplus as a smaller percentage of subscribed capital would mean less of a drain on future Fed-Treasury transfers.

\footnotetext{
${ }^{49}$ Board of Governors [13] 1959, 9/23/59, p. 3368.

${ }^{50}$ Ibid.

${ }^{51}$ Board of Governors [6] 1959, pp. 83-85, 96-99.

${ }^{52}$ Statements on the proposed legislation by Federal Reserve Board members before Congress may be found in Board of Governors [11] February 1964, pp. 148-54 and March 1964, pp. 308-20.

${ }^{53}$ Board of Governors [6] 1964, p. 212.
}

The logic of maintaining surplus at the level of subscribed capital was not easy to defend to a Congress that had changed its mind since 1919. The problem for the Fed was whether to reduce surplus voluntarily or to await legislation which might completely eliminate surplus. In December 1964, the Fed announced a voluntary 50 percent reduction in surplus to the level of paid-in capital. ${ }^{54}$ This decision added 524 million dollars to the amount transferred to the Treasury in $1965 .^{55}$ Apparently, Congress and the Treasury were satisfied since to this day FedTreasury transfers have consisted of 100 percent of net earnings after maintaining surplus at the level of paid-in capital.

\section{Recent Reserve Requirement Reform}

The first major legislative reserve requirement reform in the post-Accord era was passed in July 1959. The most important provision of that legislation authorized the Board of Governors to permit vault cash to count as required reserves. ${ }^{56}$ The legislation was not designed to make any changes in the existing system of reserve requirements that would have an important bearing on monetary policy. Rather, the reform was designed to remedy "inequities in the present system of reserve requirements [that arose] primarily from the differences among banks ... a as to their holdings of vault cash. ${ }^{657}$ The 1917 amendment to the Federal Reserve Act that prevented vault cash from counting as required reserves was said to have resulted in an inequitable situation between banks because many banks, generally smaller country banks, find it least costly for operating purposes to hold relatively larger amounts of vault cash than do other banks. But the difference between country banks and others in their vault cash holdings had been more than compensated for by lower reserve requirements for country banks, so that at the end of 1959 the ratio of vault. cash plus required reserves to net demand deposits for country banks was about 14 percent compared to about 18 percent for other banks.56

Obviously, concern for equity alone was not sufficient to account for the structure of the 1959 reserve requirement reform. This legislation was essentially

\footnotetext{
${ }^{54}$ Ibid., pp. 48-50.

${ }^{55}$ Board of Governors [11] January 1965, p. 113.

${ }^{56}$ The legislation is described in Board of Governors [11] August 1959, pp. 888-89; associated changes in Regulation D are described in Board of Governors [11] December 1959, pp. 1482-83.

${ }^{57}$ Board of Governors [11] April 1959, p. 370.

${ }^{58}$ Ibid., pp. 370-71.
} 
a means of reducing the volume of reserves that member banks had to hold. As mentioned earlier, this period marked the beginning of an exodus of banks from the Federal Reserve System that ultimately led to the passage of the Monetary Control Act of 1980. The Fed was aware then that many member banks would withdraw from the Federal Reserve System as gradually increasing interest rates raised the cost of holding noninterest-earning required reserves. The 1959 vault cash reserve requirement reform should be seen as an early post-Accord response of the Fed and the Congress to the problem of Fed membership attrition.

Reducing member bank reserve maintenance cost for a given volume of deposits, either by allowing vault cash to count as required reserves or by lowering required reserve ratios directly, necessarily reduces the demand for Fed liabilities, and thereby reduces Fed assets, net earnings, and Fed-Treasury transfers. ${ }^{59}$ Required reserves accounted for only about one-third of total Fed assets and liabilities at the end of 1960, and by the late 1970s this proportion had dropped to around one-quarter. ${ }^{60}$ The bulk of the remainder is accounted for by Federal Reserve notes held as currency. Nevertheless, Fed-Treasury transfers attributable to reserve requirements have made significant contributions to Treasury revenue. Consequently Congress and the Treasury have been highly concerned about the potential loss of revenue that follows reserve requirement reduction. Congress was, in fact, concerned about the loss of Treasury revenue that resulted from the 1959 reform allowing vault cash to count as required reserves. ${ }^{61}$ Furthermore, concern for Treasury revenue continued to play a major role in the search for a solution to the Fed membership problem.

In 1963 for example, the President's Committee on Financial Institutions concluded in discussing a proposal to reduce reserve requirements that :

\footnotetext{
${ }^{59}$ Cagan [17], pp. 188-203 presents evidence relating required reserve changes to total reserve changes.

${ }^{60}$ See Board of Governors [9], pp. 470, 533; and [7], pp. 28-29, 56 .

Since 1959 when vault cash was made eligible to satisfy reserve requirements, the ratio of member-bank required reserves to total Fed assets probably overstates the share of Fed assets attributable to reserve requirements, because if reserve requirements were eliminated the demand for excess reserves as vault cash would probably rise. On the other hand, the ratio of member bank reserve balances at the Fed to total Fed assets probably understates the share of Fed assets attributable to reserve requirements, because vault cash is probably larger than it would be without reserve requirements. Proportions given in the text lie roughly within this range.
}

${ }^{61}$ See U. S. Congress, House [49], pp. 7-36 and U. S. Congress, Senate [56], pp. 16-23, especially pp. 22-23.
Although reserve requirements serve mainly as a vehicle for monetary policy, there is, within broad limits, little basis for judging that in the long run one level is preferable to another in terms of facilitating monetary policy. Inevitably therefore the other effects of reserve requirements-on bank earnings, on competitive relationships with other institutions, and on net interest payments by the Government--become relevant in evaluating the advisability of a change in the average level of requirements. It is clear that a substantial reduction in requirements-to 10 percent or less-would, at least in the short run, result in a sizable increase in net profits of banks (especially of larger banks in reserve cities now subject to a requirement of $16^{1 / 2}$ percent) and a corresponding reduction in net receipts by the U. S. Government, taking into account payments by the Federal Reserve to the Treasury.

The Committee recommended against reducing reserve requirements, apparently because of the associated loss of Treasury revenue.

In the 1960s, Fed officials argued repeatedly but without success for universal reserve requirements on grounds that they would both ease the Fed's concern over membership attrition and would improve monetary control. ${ }^{63}$ Congressional resistance to universal reserve requirements came from supporters of the dual banking system tradition who opposed a system of universal reserve requirements on grounds that it would transfer considerable power to the Fed and undo alleged "checks and balances" in the dual banking system. In 1967 the American Bankers Association argued that universal reserve requirements were not essential for monetary control and advocated lower reserve requirements to encourage voluntary membership in the Federal Reserve System. ${ }^{64}$ But most importantly, nonmember banks simply did not want to be forced to hold noninterestearning reserves according to Fed requirements.

In September 1968, the Fed took action to reform reserve requirements that did not require Congressional legislation : it moved from contemporaneous to lagged reserve requirements. For most of the period that lagged reserve requirements have been in effect, the Fed has used the Federal funds rate as its policy instrument. With a funds rate instrument, reserve requirements made no positive contribution to monetary control. The major benefit to lagged reserve requirements has been that member

\footnotetext{
${ }^{62}$ Report of the Committee on Financial Institutions . . . [41], p. 12 .

${ }^{63}$ The Federal Reserve Board recommended universal reserve requirements in its Annual Reports from 1964 through 1968.

${ }^{64}$ Banking [3], p. 48.
} 
banks prefer it to contemporaneous reserve requirements because they feel that it allows them to reduce the cost of reserve maintenance. ${ }^{65}$ In this sense the move to lagged reserve requirements should be viewed as another Fed response to the problem of membership attrition. It lowered member banks' cost of maintaining reserves according to Fed requirements without reducing the size of the Fed portfolio or Fed-Treasury transfers.

In June 1972, the Fed took further action to reform reserve requirements that did not require Congressional legislation. The reserve city-country bank classification for reserve requirement purposes, dating back to the National Bank Act, was dropped. Under the new system the marginal reserve requirement on demand deposits rose with the volume of such deposits at a given bank. The move to graduating reserve requirements by bank size instead of by geographic location was said to be more equitable, since banks of similar size had sometimes been classified in different geographical categories for reserve requirement purposes. But the 1972 reform, like the 1968 move to lagged reserve requirements, should primarily be viewed as another Fed response to the problem of membership attrition. The new graduated system of reserve requirements was apparently constructed under the following constraints. First, it was designed to minimize aggregate release of reserves, so as to minimize the reduction in FedTreasury transfers. Second, it was not to raise reserve requirements for banks in any size class. Third, to appear equitable it was to have the marginal reserve requirement rise with deposit volume at a given bank. Finally, it was to reduce reserve requirements on small banks, who generally benefitted least from membership in the Federal Reserve System, sufficiently to induce. them to remain in the System. ${ }^{66}$

In the late 1970s Congressional attention finally

\footnotetext{
${ }^{65}$ See "Report of the Ad Hoc Subcommittee on Reserve Proposals" [40]. Lagged reserve requirements were, among other things, expected to reduce defensive open market operations. Coats [18] argues theoretically that this should not have been expected to happen and presents evidence that defensive open market operations increased with the move to lagged reserve requirements.

${ }^{66}$ These constraints are evident in the discussion in White [66]. The consequences for member banks of the 1972 reserve requirement reform were worked out by taking into account the reduction in Federal Reserve float that occurred at the same time due to a change in Fed regulations regarding check collection. See Board of Governors [11] July 1972, pp. 626-30. With this reform, the structure of reserve requirements reached its most complicated level. See the table summarizing changes in reserve requirements from 1917 to 1981 in Board of Governors [6] 1981, pp. 235-37.
}

focused productively on the growing Fed membership problem. $^{67}$ During this period the Fed offered an alternative to universal reserve requirements as a solution to the membership problem : paying interest on required reserves. In 1977, Federal Reserve Board Chairman Burns testified before the Senate Banking Committee:

In view of the apparent reluctance of the Congress to enact uniform reserve requirements for all banks, the Board has considered other proposals for ending the erosion of Federal Reserve membership. Our conclusion is that the payment of interest on required reserve balances is the most straightforward and appropriate step. ${ }^{68}$

He noted, however, that:

Since the Federal Reserve returns virtually all its net earnings to the Treasury, payment of interest on required reserve balances would reduce Treasury revenues-something, let me note with some emphasis, that would not occur if the Congress were to enact uniform reserve requirements [for all banks]. ${ }^{69}$

In 1978, the Fed went so far as to suggest that it did not need Congressional approval to pay interest on reserves and proposed to implement its own plan. Congressional reaction, as expressed in a joint letter to Federal Reserve Board Chairman Miller from Representative Reuss and Senator Proxmire (Chairmen of the House and Senate Banking Committees respectively) was strong :

We believe unilateral action by the Board to pay interest on reserve, balances would constitute a blatant usurpation of Congressional powers and would raise profound questions about the continued independence of the Fed. We can think of no other action by the Board that could do as much to undermine confidence and trust in the Board on the part of those key members of Congress who feel strongly on this issue.

In the absence of legislative limitations, the payment of interest on reserve balances, however modestly begun, could ultimately add billions of dollars to the federal deficit and could be viewed as a precedent for carte blanche authority for the expenditure of Federal Reserve bank earnings without restraint by either the Executive or Legislative branch of the government. With Reserve

\footnotetext{
${ }^{67}$ The Federal Reserve Board published legislative recommendations for dealing with the membership problem in each of its 1970 s Annual Reports. Figures describing the extent of membership attrition are reported in Board of Governors [6] 1978, p. 316 and 1979, p. 253. Board of Governors [6] 1978, p. 317, reported an estimate, using 1977 data, of the aggregate burden to member banks of Federal Reserve membership in excess of 650 million dollars, or about 9 percent of member bank profits before taxes.
}

${ }^{68}$ Arthur F. Burns, in U. S. Congress, Senate [61], p. 30.

${ }^{69}$ Ibid 
bank earnings now running in the neighborhood of $\$ 7$ billion annually, the payment of any part of these earnings to commercial banks can be viewed as the opening wedge in a serious breach of the Constitutional power of the Congress and the President to control federal spending and determine the fiscal policy of the nation. ${ }^{70}$

The impact on Fed-Treasury transfers of various proposed solutions to the Fed membership problem was a major concern throughout Congressional hearings in 1977, 1978, and 1979. Proposed legislation before the Senate Banking Subcommittee on Financial Institutions in 1977 authorizing the Fed to pay interest on required reserves limited the total interest payment to 10 percent of Fed net earnings. ${ }^{71}$ At that time, Chairman Burns requested that the limit be raised to 1.5 percent but assured the Subcommittee that the Federal Reserve Board intended "to keep the net cost to the Treasury as low as possible." ${ }^{62}$

The 1978 Federal Reserve Board proposal to pay interest on required reserves offered a relatively low 7 percent net earnings limit on total interest paid but also proposed lower reserve requirements. The plan included provisions to price Fed services, which had been provided without explicit charge, and to transfer a portion of Reserve Bank surplus to the Treasury in order to minimize loss of Treasury revenue during a transition period. ${ }^{73}$ With the program fully in place, the Board argued that Fed-Treasury transfers would be reduced by 300 million dollars per year, but pointed out that continued attrition of deposits subject to Fed reserve requirements would cause a substantial decline in Fed-Treasury transfers in the absence of the program. Since the program was expected to reduce, if not eliminate, such deposit attrition, on net the Board argued that the cost to the Treasury would be minimal. The Board pointed out, however, that the impact on Treasury revenue would be more favorable if Congress enacted the Board's proposed universal reserve requirement legislation. $^{74}$

In 1979 hearings before the Senate Banking Committee, Senator Proxmire declared that he regarded the protection of Treasury revenues as an "obligation" of the Committee, and warned that transfers

\footnotetext{
${ }^{70}$ U. S. Congress, House [52], p. 781.

${ }^{71}$ U. S. Congress, Senate [61], pp. 806-7.

${ }^{72}$ Ibid., p. 36.

${ }^{73}$ U. S. Congress, House [52], pp. 122-31.

${ }^{74}$ Ibid., pp. 130-31.
}

away from the Treasury "would result in an increased Federal deficit which in today's inflationary environment must be held as low as possible. ${ }^{675}$ The Administration itself placed an implicit limit on the cost of an acceptable reform package, as indicated in 1979 testimony by Deputy Secretary of the Treasury Robert Carswell:

In testimony before [the Senate Banking Committee] last June and August and in a letter to the House Banking Committee in September 1977, the administration stated that it would accept a revenue loss of $\$ 200-300$ million, after tax recoveries, to deal with this problem. ... In the current budget environment, a solution to the membership problem involving a revenue loss under $\$ 200$ million, net of tax recoveries, is essential.76

The legislation which emerged as the Monetary Control Act of 1980 (MCA) was a compromise among interests represented by the various groups. The Fed's concern was to reduce membership attrition. Membership was to remain voluntary according to the dual banking system tradition, but a solution incorporating either universal reserve requirements or interest on required reserves would have greatly reduced the incentive to withdraw from the Federal Reserve System and would have largely solved the Fed membership problem. The Treasury was concerned primarily for the protection of its revenue and accordingly tended to prefer universal reserve requirements to interest on required reserves. ${ }^{77} \mathrm{Mem}-$ ber banks may have preferred interest on reserves, but universal reserve requirements would at least relieve them of a competitive disadvantage relative to nonmembers. In addition, member banks could benefit from universal reserve requirements because reserve requirement ratios necessary to generate an acceptable volume of Fed-Treasury transfers could be lower with the extension of reserve requirements to nonmembers. Lastly, nonmember depository institutions obviously preferred that the Fed pay interest on member bank required reserves, since universal requirements would force them to hold noninterest-

\footnotetext{
${ }^{75}$ U. S. Congress, Senate [60], p. 2.

${ }^{76}$ Ibid., p. 525 .

${ }^{77}$ In 1977 , the Treasury apparently backed payment of interest on required reserves as part of a solution to the Fed membership problem. But by 1979 the Treasury was opposed to interest on required reserves. The evolution of the Treasury's position is evident in statements by W. Michael Blumenthal, Secretary of the Treasury, in U. S. Congress, Senate [61], pp. 8-9; and Robert Carswell, Deputy Secretary of the Treasury, in U. S. Congress, Senate [59], pp. 193-94 and in U. S. Congress, Senate [60], pp. 523, 529.
} 
earning reserves at the Fed. The solution to the Fed membership problem adopted by Congress in the MCA reduced reserve requirements and made them universal, thereby essentially satisfying the Fed, the Treasury, and member banks. ${ }^{78}$

The losers are the nonmember depository institutions who were required to meet Fed reserve requirements, and the state banking supervisors who lost an important distinction in the dual banking system which they had tried hard to preserve. ${ }^{79}$ Universal reserve requirements represent a major departure from the dual banking system tradition. While Fed membership remains voluntary, a constraint on Fed power implicit in voluntary. membership has been substantially weakened since all depository institutions must hold reserves according to Fed requirements regardless of membership.

The reserve requirement reduction is important in making the new mandatory requirements less burdensome for members and nonmembers. It also reduces the competitive disadvantage of reservable deposits relative to competing nonreservable instruments outside the Fed's jurisdiction, such as money market mutual fund shares and Eurodollar deposits. Obviously, the reserve requirement reduction eliminates some Fed earnings which would otherwise have gone to the Treasury, though Treasury losses could be somewhat offset by higher tax revenues from increased bank profits.

The MCA also directs the Fed to price its services. ${ }^{80}$ This reform gives banks a chance to effectively compete against the Fed for correspondent banking business, while simultaneously eliminating a drain on Fed earnings and Fed-Treasury transfers that had previously resulted from Fed services being provided to member banks without explicit charge.

The legislative history of the Monetary Control

\footnotetext{
${ }^{78}$ Interestingly, George Benston, writing in 1978 about likely solutions to the Fed membership problem, predicted that universal reserve requirements would "not be instituted so long as only nonmember institutions would lose and nobody else would clearly or significantly gain." Benston [5], p. 62.

${ }^{79}$ See William C. Harris, Conference of State Bank Supervisors, in U. S. Congress, Senate [58], pp. 41-46. The American Bankers Association (ABA) had also opposed universal reserve requirements through 1979. See John H. Perkins, President of the American Bankers Association, in U. S. Congress House [51], pp. 535-36. But interestingly, in 1980 the ȦBA came out in support of universal reserve requirements. See C. C. Hope, Jr., President of the American Bankers Association, in U. S. Congress, Senate [58], pp. 125-27.
}

${ }^{80}$ See Board of Governors [10], pp. 447-48.
Act indicates that concern for Treasury revenue significantly affected the course of the debate on reserve requirement reform in the $\mathrm{MCA}$. Despite the fact that reserve requirements have only been responsible for a relatively small fraction of total Fed-Treasury transfers, the sums involved have been large enough to warrant considerable effort by the Treasury to influence the outcome of the reforms. As mentioned above, either some form of payment of interest on reserves or universal reserve requirements would have largely solved the Fed membership problem ; the former would have satisfied both member and nonmember depository institutions as well as the Fed. But the Treasury preferred universal reserve requirements because payment of interest on reserves would have greatly reduced Fed-Treasury transfers. Concern for maintaining Treasury revenue accounts for the fact that universal reserve requirements rather than the payment of interest on reserves was ultimately adopted by Congress as the solution to the Fed membership problem in the MCA. ${ }^{81}$

IV.

\section{CONCLUSION}

Reserve requirements at the national level have been supported by a succession of three prominent rationales, namely, that reserve requirements have been necessary for liquidity provision, Federal Reserve credit policy, and monetary control. However, reserve requirements have never served these functions well, and often have not served them at all. Although fractional reserve requirements contributed somewhat to individual bank liquidity, banking crises in the National Banking era and in the early 1930s demonstrated that reserve requirements could not guarantee liquidity for the banking system as a whole.

The role played by reserve requirements in Fed credit policy in the interwar period varied greatly. From the early years of the Federal Reserve System through the 1920s the Fed relied on the discount rate as its primary policy instrument. Credit conditions were managed by manipulating the discount rate ; but credit, money, and reserve demand were essentially

\footnotetext{
${ }^{81}$ The extent to which concern for maintenance of Treasury revenue came to dominate the solution to the Fed membership problem adopted in the MCA is evident in U. S. Congress, House [50], especially the dissenting views, and in testimony by Paul A. Volcker, Chairman of the Federal Reserve Board, in U. S. Congress, Senate [58], pp. 4-39, especially pp. 10-11.
} 
accommodated at a given discount rate so that reserve requirements did not effectively restrain credit expansion during those years. In particular, reserve requirements did not function well to restrain credit expansion during the stock market boom of 1928 and 1929. In the 1930s credit demand was low, excess reserves were large, and reserve requirements were not then important for restraining credit expansion. However, reserve requirements were useful for the Fed to immobilize excess reserves which it then regarded as excessive.

During the period of increasing concern for monetary control dating from the 1950s, free reserves and the Federal funds rate were both utilized as operating variables, with the Federal funds rate emerging as the primary policy instrument in the early 1970s. In the 1970s money growth was managed by manipulating the funds rate. Previously, money and credit conditions were managed by manipulating the target for free reserves and the discount rate. With either of these operating procedures, reserves are merely supplied as required to support the quantity of money and credit demanded given the operating target. Since both the free reserve/discount rate and Federal funds rate operating procedures are essentially accommodative, reserve requirements did not exercise an effective constraint on monetary expansion during the post-Accord period in which these operating procedures were utilized.

Since October 1979, the Fed has used nonborrowed reserves as its monetary control instrument. But the post-October 1979 monetary control procedure, employing a nonborrowed reserve instrument with lagged reserve requirements, amounts to targeting net borrowed reserves in any given reserve statement week. However, net borrowed or free reserve targeting is accommodative, so even after the adoption of a nonborrowed reserve operating procedure in October 1979, reserve requirements still do not exercise an effective constraint on monetary expansion.

While net borrowed reserve and nonborrowed reserve targeting are identical within a reserve statement week, they are different in their dynamic response to money stock targeting error. A predetermined net borrowed reserve path embodies no automatic mechanism to correct money stock targeting error. By contrast, nonborrowed reserve targeting can embody an automatic corrective feedback mechanism. However, the automatic corrective response to money stock targeting error under the post-October 1979 nonborrowed reserve-lagged reserve requirements monetary control procedure could be duplicated without imposition of reserve requirements.
In contrast to the relatively minor role that reserve requirements have played in liquidity provision and in implementing the Fed's credit and monetary control policies, reserve requirements have consistently functioned to provide revenue for the United States Treasury. Furthermore, financing considerations have substantially influenced reserve requirement legislation throughout the history of the Federal Reserve System. Reserve requirement reform in the early years of the Federal Reserve System was largely designed to enhance the Fed's power to create money in order to provide reserves to the banking system, to meet its own financial needs, and to finance United States participation in World War I.

Since the Accord, rising inflation and interest rates have increased the cost of holding noninterestearning required reserves at the Fed. Fed noninterest-earning reserve requirements put member banks at a disadvantage relative to nonmembers who generally had lower reserve requirements and were allowed to hold interest-earning assets as reserves. Because membership in the Federal Reserve System is voluntary under the dual banking system tradition, increasing numbers of banks withdrew from the System over this period as a result of the increasing cost of maintaining required reserves at the Fed. Major reserve requirement reform during this period prior to the Monetary Control Act was largely designed to reduce the cost of meeting Fed reserve requirements and should be viewed as a response to the problem of Fed membership attrition.

Reducing member bank reserve requirements for a given deposit volume necessarily reduces the demand for Fed liabilities, and thereby reduces Fed assets and Fed-Treasury transfers. Fed reserve requirements have only accounted for a small fraction of Fed liabilities, the bulk being accounted for by Federal Reserve notes held as currency. Nevertheless, Fed-Treasury transfers attributable to reserve requirements have contributed significantly to Treasury revenue during this period. Consequently, Congress and the Treasury have been highly concerned about the potential loss of revenue that follows from reducing the cost to member banks of holding required reserves at the Fed either by lowering reserve requirements or by paying interest on required reserves. That concern played a major role in the solution to the Fed membership problem adopted in the Monetary Control Act of 1980.

Even though reserve requirement reform embodied in the Monetary Control Act appears to have been motivated largely by concern for the Fed membership problem and Treasury revenue, the reserve requirement reform could significantly improve monetary 
control if followed up with further reform. Specifically, with contemporaneous reserve requirements and a nonborrowed or total reserve instrument, the money multiplier could provide a valuable operational link between reserves and the targeted money stock.
Reserve requirements and the Monetary Control Act reforms could then contribute significantly to monetary control by stabilizing the money multiplier and tightening the link between the reserve instrument and the targeted money stock.

\section{References}

1. Auernheimer, Leonardo. "The Honest Government's Guide to the Revenue from the Creation of Money." Journal of Political Economy. (May/ June 1974), pp. 598-606.

2. Axilrod, Stephen H. "The FOMC Directive as Structured in the Late 1960's: Theory and Appraisal." In Open Market Policies and Operating Procedures-Staff Studies, pp. 1-36. Washington: Board of Governors of the Federal Reserve System, 1971.

3. Banking, January 1967.

4. Barro, Robert 3. "Measuring the Fed's Revenue from Money Creation." National Bureau of Economic Research Working Paper Series, no. 883, April 1982.

5. Benston, George J. Federal Reserve Membership: Consequences, Costs, Benefits and Alternatives. Prepared for the Trustees of the Banking Research Fund, Association of Reserve City Bankers. Chicago, 1978.

6. Board of Governors of the Federal Reserve System. Annual Report. Washington, various years.

7. Annual Statistical Digest, 1970-1979. Washington, 1981

8. Banking and Monetary Statistics, 1914-1941. Washington, 1943; reprinted 1976.

9. Banking and Monetary Statistics, 1941-1970. 'Washington, 1976.

10. "The Depository Institutions Deregulation and "Monetary Control Act of 1980." Federal Reserve Bulletin (June 1980), pp. 444-53. 11. issues. Federal Reserve Bulletin, various

12. "The History of Reserve Requirements for Banks in the United States." Federal Reserve Bulletin (November 1938), pp. 953-72.

13. "Minutes of the Board of Governors of the Federal Reserve System." Washington, various years. (Processed.)

14. "Minutes of Federal Open Market Committee." Washington, various years. (Processed.)

15. Rules and Regulations.

16. "The Burden of Federal Reserve Membership, NOW accounts, and the Payment of Interest on Reserves." Staff Paper, Board of Governors of the Federal Reserve System. Washington, June 1977. (Processed.)

17. Cagan, Phillip. Determinants and Effects of Changes in the Stock of Money: 1875-1960. New York : Columbia University Press, 1965.

18. Coats, Warren L., Jr. "Lagged Reserve Accounting and the Money Supply Mechanism." Journal of Money, Credit, and Banking (May 1976), pp. $167-80$.
19. Commercial and Financial Chronicle, selected issues.

20. Committee on Bank Reserves. "Member Bank Reserves-Report of the Committee on Bank Reserves of the Federal Reserve System." In Annual Report 1932, pp. 260-85. Washington: Board of Governors of the Federal Reserve System, 1933.

21. Congressional Record, vol. 51.

22. Davis, Andrew MacFarland. "The Origin of the National Banking System." In Publications of National Monetary Commission, vol. V. U. S. National Monetary Commission. Washington : Government Printing Office, 1911-12.

23. Federal Reserve Act As Amended Through 1976 Washington: Board of Governors of the Federal Reserve System, 1976

24. "Federal Reserve Act of 1913." In Annual Report 1914, pp. 25-44. Washington: Board of Governors of the Federal Reserve System, 1915.

25. Federal Reserve Bank of New York. Bank Reserves: Some Major Factors Affecting Them. New York, March 1951.

26. "The Significance and Limitations of Free Reserves." Monthly Review, Federal Reserve Bank of New York (November 1958), pp. 162-67.

27. Federal Reserve Committee on Branch, Group, and Chain Banking. "The Dual Banking System in the United States." Prepared for the Federal Reserve System. Washington: Federal Reserve Board, n.d.

28. Friedman, Milton and Schwartz, Anna 3. A Monetary History of the United States: 1867-1960. Princeton : Princeton University Press, 1963.

29. Goodfriend, Marvin. "Discount Window Borrowing, Monetary Control, and the Post-October 6 1979 Federal Reserve Operating Procedure." Federal Reserve Bank of Richmond Working Paper 81-1, January 1981.

30. "A Model of Money Stock Determination with Loan Demand and a Banking System Balance Sheet Constraint." Economic Review, Federal Reserve Bank of Richmond (January/ February 1982), pp. 3-16.

31. "A Prescription for Monetary Policy 1981." Economic Review, Federal Reserve Bank of Richmond (November/December 1981), pp. 11-18.

32. Hackley, Howard H. Lending Functions of the Federal Reserve Banks: A History. Washington: Board of Govemors of the Federal Reserve System, 1973.

33. Hammond, Bray. Banks and Polities in America, from the Revolution to the Civil War. Princeton: Princeton University Press, 1957.

34. Sovereignty and an Empty Purse: Banks and Politics in the Civil War. Princeton: Princeton University Press, 1970. 
35. McCallum, Bennett T. "Price Level Determinacy with an Interest Rate Policy Rule and Rational Expectations." Journal of Monetary Economics (November 1981), pp. 319-29.

36. Meigs, A. James. Free Reserves and the Money Supply.. Chicago: University of Chicago Press,

37. Million, John Wilson. "The Debate on the National Bank Act of 1863." Journal of Political Economy (March 1894), pp. 251-80.

38. Newcomb, Simon. A Critical Examination of our Financial Policy During the Southern Rebellion. New York: Appleton, 1865; reprint ed., New York: Gārlānd Publishing Co., Inc., 1974.

39. Original Acts Pertaining to National Banks in Chronological Order, vol. 1. Washington: U. S. Treasury Department, Comptroller of the Currency. (Processed.)

40. "Report of the Ad Hoc Subcommittee on Reserve Proposals." Federal Reserve Banks. Committee on Banking and Credit Policy. Ad Hoc Subcommittee on Reserve Proposals. Robert P. Black, Chairman. May 13, 1966. (Processed.)

41. Report of the Committee on Financial Institutions to the President of the United States. Walter W. Heller, Chairman. Washington: Government Printing Office, 1963.

42. Rodkey, Robert G. Legal Reserves in American Banking. Michigan Business Studies, vol. VI, no. 5. Ann Arbor: University of Michigan, 1934.

43. Sargent, Thomas J. and Wallace, Neil. "The RealBills Doctrine versus the Quantity Theory: A Reconsideration." Journal of Political Economy (December 1982), pp. 1212-36.

44. Smith, Warren L. "Reserve Requirements in the American Monetary System." In Monetary Management, pp. 175-315. Prepared for the Commission on Money and Credit. Englewood Cliffs, N. J.: Prentice-Hall, Inc., 1963.

45. Sprague, O. M. W. History of Crises Under the National Banking System. Prepared for the National Monetary Commission, 1910; reprint ed., New York: Augustus M. Kelley, 1968.

46. Stein, Herbert. The Fiscal Revolution in America. Chicago: University of Chicago Press, 1969.

47. U. S. Congress. House. Amendments to Federal Reserve Act. H.R. Report 1026 to accompany S. 5236, 65th Congress, 3rd session, 1919.

48. Changes in the Banking and Currency System of the United States. H.R. Report 69 to accompany H.R. 7837, 63rd Congress, 1st session, 1913.

49. Member Bank Reserve Requirements. H.R. Report 403 on S. 1120, 86th Congress, 1st session, 1959 .

50. Monetary Control Act of 1979. H.R. Report 96-263 to accompany H.R. 7, 96th Congress, 1st session, 1979 .

51. U. S. Congress. House. Committee on Banking, Finance and Urban Affairs. Monetary Control. Hearings before the Committee on Banking, Finance and Urban Affairs on H.R. 7, Serial 96-6, 96th Congress, 1st session, 1979.

52.

Monetary Control and the Membership Problem. Hearings before the Committee on Banking, Finance and Urban Affairs on H.R. 13476, H.R. 13477, H.R. 12706, and H.R. 14072 , 95th Congress, 2nd session, 1978.
53. U. S. Congress. House. Subcommittee of the Committee on Banking and Currency. Banking and Currency Reform. Hearings before the Subcommittee of the Committee on Banking and Currency, 62nd Congress, 3rd session, 1913.

54. U. S. Congress. Senate. Banking and Currency. S. Report 133, Part 2 to accompany H.R. 7837 , 63rd Congress, 1st session, 1913.

55. Expenses of Federal Reserve Banks. S. Document 75, 67th Congress, 1st session, 1921.

56. Member Bank Reserve Requirements. S. Report 195 to accompany S. 1120, 86th Congress, 1st session, 1959.

57. U. S. Congress. Senate. Committee on Banking and Currency. Banking and Currency. Hearings before the Committee on Banking and Currency on H.R. 7837 (S. 2639), 3 volumes, 63rd Congress, 1st session, 1913.

58. U. S. Congress. Senate. Committee on Banking, Housing, and Urban Affairs. Federal Reserve Requirements. Hearings before the Committee on Banking, Housing, and Urban Affairs on S. 353 and proposed amendments, S. 85, and H.R. 7, 96th Congress, 2nd session, 1980.

59. - Federal Reserve Requirements Act of 1978. Hearings before the Committee on Banking, Housing, and Urban Affairs on S. 3304, 95th Congress, 2nd session, 1978

60. Monetary Policy Improvement Act of 1979. Hearings before the Committee on Banking, Housing, and Urban Affairs on S. 85 and S. 353, 96th Congress, 1st session, 1979.

61. NOW Accounts, Federal Reserve Membership and Related Issues. Hearings before the Subcommittee on Financial Institutions of the Committee on Banking, Housing, and Urban Affairs on S. 1664-1669, and S. 1873, 95th Congress, 1st session, 1977.

62. U. S. Department of Commerce. Bureau of Economic Analysis. The National Income and Product Accounts of the United States, 1929-76: Statistical Tables. Washington: U. S. Government Printing Office, 1981.

63. $\quad$ Survey of Current Business (July $1982)$

64. U. S. National Monetary Commission. "Report of the National Monetary Commission," "Suggested Plan for Monetary Legislation," and "Suggested Plan for Monetary Legislation-Revised Edition." In Publications of National Monetary Commission, vol. I. U. S. National Monetary. Commission. Washington: U. S. Government Printing Office, 1911-12

65. Warburg, Paul M. The Federal Reserve System, Its Origin and Growth. 2 volumes. New York: The MacMillan Company, 1930.

66. White, H. "Operational Considerations Regarding Determination of Reserve Requirements., Staff Memo, Board of Governors of the Federal Reserve System. Washington, January 1972. (Processed.)

67. Willis, Henry Parker. The Federal Reserve System. New York: The Ronald Press Company, 1923

68. Wingfield, B. Magruder. "Deterrents to Membership in the Reserve System." In Banking Studies, pp. 273-92. Washington: Board of Governors of the Federal Reserve System, 1941; reprinted 1947. 